\title{
Application of Anammox-Based Processes in Urban WWTPs: Are We on the Right Track?
}

\author{
Alba Pedrouso ${ }^{1}$ D, José Ramón Vázquez-Padín ${ }^{2}$ D , Dafne Crutchik ${ }^{3}$ and José Luis Campos ${ }^{3, *(D)}$ \\ 1 Department of Chemical Engineering, CRETUS Institute, Universidade de Santiago de Compostela, \\ Rua Lopez de Marzoa s/n, E-15872 Santiago de Compostela, Spain; alba.pedrouso@usc.es \\ 2 Aqualia, Guillarei WWTP, Camino de la Veiga s/n, E-36720 Tui, Spain; jvazquezp@fcc.es \\ 3 Facultad de Ingeniería y Ciencias, Universidad Adolfo Ibáñez, Avda. Padre Hurtado 750, \\ Viña del Mar 2503500, Chile; dafne.crutchik@uai.cl \\ * Correspondence: jluis.campos@uai.cl
}

Citation: Pedrouso, A.;

Vázquez-Padín, J.R.; Crutchik, D.;

Campos, J.L. Application of

Anammox-Based Processes in Urban WWTPs: Are We on the Right Track? Processes 2021, 9, 1334. https:// doi.org/10.3390/pr9081334

Academic Editors: Albert Magrí and Tommaso Lotti

Received: 12 June 2021

Accepted: 28 July 2021

Published: 30 July 2021

Publisher's Note: MDPI stays neutral with regard to jurisdictional claims in published maps and institutional affiliations.

Copyright: (c) 2021 by the authors. Licensee MDPI, Basel, Switzerland. This article is an open access article distributed under the terms and conditions of the Creative Commons Attribution (CC BY) license (https:/ / creativecommons.org/licenses/by/ $4.0 /)$.

\begin{abstract}
The application of partial nitritation and anammox processes (PN/A) to remove nitrogen can improve the energy efficiency of wastewater treatment plants (WWTPs) as well as diminish their operational costs. However, there are still several limitations that are preventing the widespread application of PN/A processes in urban WWTPs such as: (a) the loss of performance stability of the $\mathrm{PN} / \mathrm{A}$ units operated at the sludge line, when the sludge is thermally pretreated to increase biogas production; (b) the proliferation of nitrite-oxidizing bacteria (NOB) in the mainstream; and (c) the maintenance of a suitable effluent quality in the mainstream. In this work, different operational strategies to overcome these limitations were modelled and analyzed. In WWTPs whose sludge is thermically hydrolyzed, the implementation of an anerobic treatment before the PN/A unit is the best alternative, from an economic point of view, to maintain the stable performance of this unit. In order to apply the PN/A process in the mainstream, the growth of ammonia-oxidizing bacteria (AOB) should be promoted in the sludge line by supplying extra sludge to the anaerobic digesters. The AOB generated would be applied to the water line to partially oxidize ammonia, and the anammox process would then be carried out. Excess nitrate generated by anammox bacteria and/or NOB can be removed by recycling a fraction of the WWTP effluent to the biological reactor to promote its denitrification.
\end{abstract}

Keywords: autotrophic nitrogen removal; effluent quality; energy efficiency; mainstream; nitritation; sludge thermal hydrolysis

\section{Introduction}

Improving the energy efficiency of urban wastewater treatment plants (WWTPs) is a crucial step for decreasing their operating costs and environmental impact. Accordingly, numerous new technologies and processes have been proposed to decrease energy consumption [1]. Since aeration has the greatest energy cost, much work has focused on replacing the aerobic degradation of organic matter with anaerobic degradation under conditions suitable for the production of biogas. As a result, energy recovery from organic matter is maximized and energy requirements are minimized. Processes such as membrane filtration, chemically enhanced primary treatment, or adsorption/bio-oxidation can be applied in the mainstream to concentrate organic matter and redirect it towards the sludge line [2-4]. This redirection improves the WWTPs energy efficiency but may compromise their effluent quality in terms of nitrogen compounds. Nitrogen is generally removed in the mainstream by applying nitrification/denitrification processes that require $6-8 \mathrm{~g} \mathrm{COD} / \mathrm{g}$ $\mathrm{N}$ to ensure complete denitrification [5]. In this context, the application of autotrophic partial nitritation and anammox (PN/A) processes for nitrogen removal instead of the conventional nitrification/denitrification processes would allow for an increase in the WWTP energy efficiency while also meeting the nitrogen disposal requirements. In fact, 
if the removal of nitrate generated by anammox bacteria is considered, $0.31 \mathrm{~g}$ COD/g N would be required for nitrogen removal [6]. Siegrist et al. [7] reported that a $52 \%$ reduction in the total energy consumption of WWTPs could be achieved through the implementation of PN/A processes in the sludge line. The achievement of energy savings, together with the availability of different technologies capable of providing a quick start-up and a stable operation, have motivated the full-scale implementation of the PN/A processes in the WWTP sludge line [8,9]. However, the current trend of applying a thermal hydrolysis pretreatment (THP) at the sludge line to improve the rate of anaerobic digestion is causing operational stability problems in the PN/A units. These issues are attributed to the increase of both ammonia and organic matter concentrations in the supernatant stream coming from anaerobic digesters [10-12]. Therefore, new operating strategies should be developed to maintain the proper performance of the PN/A units.

The latest research on anammox-based processes has focused mainly on their application to the mainstream of urban WWTPs. The literature shows, however, that wastewater temperatures are generally lower than $20{ }^{\circ} \mathrm{C}$. This low temperature is one of the main bottlenecks for the successful implementation of PN/A processes in the mainstream since it favors the development of nitrite oxidizing bacteria (NOB) over both ammonia-oxidizing (AOB) and anammox bacteria, thus causing ammonia to be oxidized to nitrate instead of nitrogen gas $[13,14]$. On the other hand, the nitrate generated by both NOB and anammox bacteria, in addition to the remaining ammonia and nitrite, can cause the effluent from mainstream PN/A units to exceed strict nitrogen disposal requirements [15]. In order to overcome these drawbacks, different control strategies have been proposed to avoid NOB proliferation [16], while the combination of PN/A processes with others involved in the nitrogen cycle seems to be the way to improve effluent quality [17]. At this moment, there is only one WWTP where a combination of partial nitritation, anammox, and denitrification processes is applied at full scale to remove nitrogen [18]. This WWTP takes advantage of the fact that wastewater temperature is around $30{ }^{\circ} \mathrm{C}$, which favors both the growth of AOB and anammox bacteria over the growth of NOB. The paucity of real-life applications contrasts with the number of full-scale facilities already implemented in the sludge line [8,9], indicating that the technology for applying PN/A processes in the mainstream is not yet sufficiently mature to guarantee a suitable effluent quality.

Hence, this work focuses on proposing, modelling, and analyzing different operational strategies to overcome the most critical aspects limiting the application of PN/A processes in urban WWTPs such as: (a) the loss of performance stability of the PN/A units operated at the sludge line, when the sludge is thermally pretreated; (b) the proliferation of NOB in the mainstream; (c) the challenge of obtaining a suitable effluent quality in the mainstream.

\section{Implications of Thermal Pre-Hydrolysis Units at the Sludge Line}

Technologies based on the anammox process, mainly those using PN/A single-stage configurations, are being successfully applied at full scale for the removal of nitrogen from the supernatants of anaerobic sludge digesters (AD) in order to improve WWTP energy balance [19]. Further improvements are achieved if sludge pretreatment units are also implemented to increase the overall rate of the anaerobic digestion process. The sludge pretreatment increases the digestion capacity of the existing facilities while allowing for the addition of external organic waste to the sludge in order to increase the amount of biogas generated in the WWTPs [20]. Among the sludge pretreatment technologies, those based on thermal hydrolysis are the most widely used, with CAMBI being the dominant technology implemented at full scale [21,22]. In order to minimize the energy required by THP units, the sludge is subjected to double centrifugation in order to be able to introduce it into the CAMBI system at the highest concentration possible. However, the use of sludge THP units leads to a rise in the ammonium concentration inside the anaerobic digesters, from values of 1000-1300 $\mathrm{mg} \mathrm{NH}_{4}{ }^{+}-\mathrm{N} / \mathrm{L}$, when no THP is applied, to 1800-2300 $\mathrm{mg} \mathrm{NH}_{4}{ }^{+}-\mathrm{N} / \mathrm{L}[10,23,24]$. This rise negatively affects the performance of the subsequent nitrogen removal systems due to different factors: 
1. A direct effect: The increase of the inlet ammonium concentration increases the risk of inhibition of $\mathrm{AOB}$ and anammox bacteria by both free ammonia $\left(\mathrm{NH}_{3}\right)$ and free nitrous acid $\left(\mathrm{HNO}_{2}\right)$. To guarantee operational safety conditions, full-scale $\mathrm{PN} / \mathrm{A}$ units are generally operated at inlet ammonium concentrations of around $1000 \mathrm{mg} \mathrm{N}-\mathrm{NH}_{4}{ }^{+} / \mathrm{L}$. To achieve this, a 1:1 dilution is usually applied to the effluents from anaerobic digesters fed with thermally hydrolyzed sludge [10,23,25]. This operational strategy has the disadvantage of having to heat the water used for dilution in order to maintain a temperature of around $30^{\circ} \mathrm{C}$ and avoid a decrease in biomass activity that would hinder the ammonium removal [26].

2. An indirect effect: The increase in ammonium concentration also affects the performance of the AD process due to the inhibitory effect of the former on methanogenic (acetoclastic) bacteria, which leads to an increase in the concentration of biodegradable organic matter in the effluent [27]. Moreover, anaerobic digesters fed with prehydrolyzed sludge are generally operated at lower solid retention times (SRT) than those fed with raw sludge, thus promoting the presence of biodegradable organic matter in their effluent (Figure 1, calculations details are provided in the Supplementary Section). The literature shows that the concentration of volatile fatty acids (VFAs) in the sludge of anaerobic digesters increases when the sludge is thermally pretreated [28]. Therefore, the implementation of THP units in the sludge line leads to an increase of the $\mathrm{COD}_{\text {biodegradable }} / \mathrm{N}$ ratio up to values around $1.2 \mathrm{~g} / \mathrm{g}$, or even higher, when the anaerobic digesters become unstable $[10,11]$. These values exceed the limit of $0.5 \mathrm{~g} / \mathrm{g}$ recommended for the operation of single-stage PN/A systems under stable conditions [29]. This high concentration of organic matter would affect both AOB and anammox bacteria activities $[11,30]$.

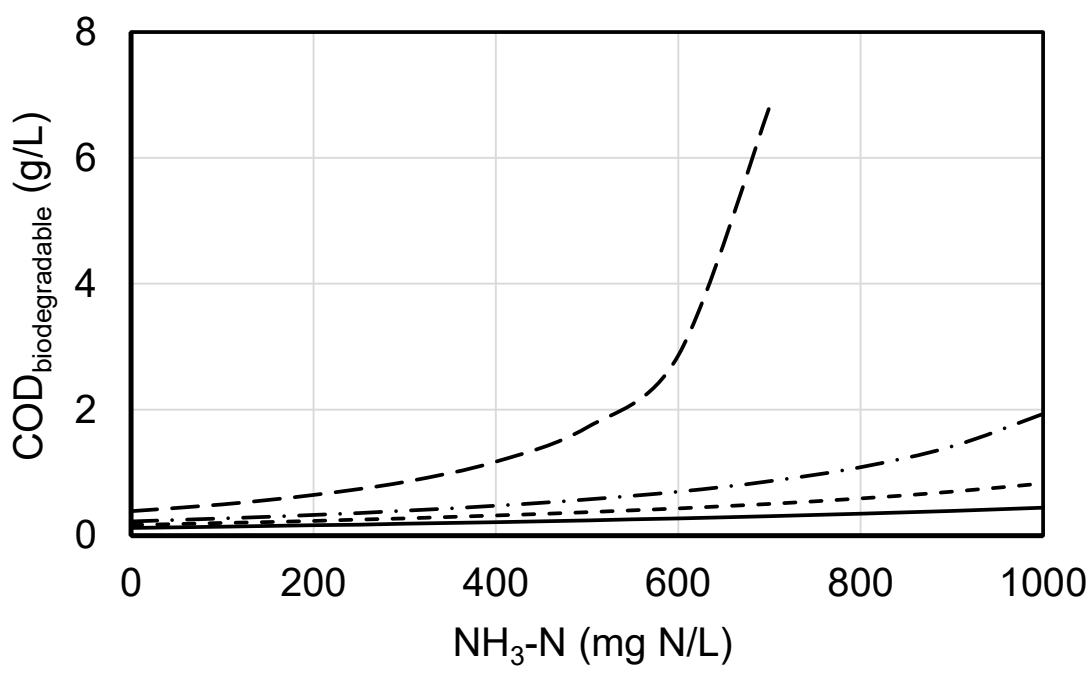

Figure 1. Biodegradable organic matter concentration expected in the effluent of an anaerobic sludge digester, depending on the level of free ammonia (SRT: $--10 \mathrm{~d}$; $-\cdot-15 \mathrm{~d}$; - - - $20 \mathrm{~d}$; $-30 \mathrm{~d}$ ).

In recent years, several publications have focused on the organic matter present in anaerobic digester effluents treating thermally hydrolyzed sludge (THP/AD) and its inhibitory effects on the performance of single-stage PN/A nitrogen removal systems [10-12]. According to Zhang et al. [11], these effects may be attributed to both a direct inhibition on the growth rate of $\mathrm{AOB}$ and anammox bacteria, and a substrate diffusional limitation caused by the presence of the COD particulate and colloidal fractions. To counteract these inhibitory effects, Zhang et al. [10] proposed to increase the dissolved oxygen (DO) level at which those systems are operated to promote AOB activity, and consequently, the degradation of organic compounds. Such inhibitory effects can also be overcome by applying a biological pretreatment (aerobic or anaerobic) to the AD effluents [11,26] or by using a two-stage autotrophic system to remove nitrogen [31,32]. Based on these facts, 
the reported inhibitory effects could be associated with the biodegradable fractions of the organic matter since they would be removed during the biological pretreatments or at the PN stage upon the application of a two-stage nitrogen removal system. According to the results obtained by Driessen et al. [26] at a full-scale facility, the initial organic matter removal by means of a Phospaq reactor would also allow for the reduction of the degree of dilution applied to the THP / AD effluents without compromising the operational stability of the subsequent single-stage PN/A system. In the case of using two-stage nitrogen removal systems, the THP/AD effluents can be treated under stable conditions without applying any dilution [31,32]. Therefore, a suitable strategy to remove the organic matter could also reduce the risk of process destabilization associated with the presence of high ammonia concentrations. In fact, Ochs et al. [12] attributed the loss of operational stability in the single-stage PN/A systems to organic/nitrogenous overloads rather than to possible inhibitory effects related to the characteristics of the influent, and hence proposed the implementation of effective control systems to avoid operational destabilization episodes.

In order to maintain the proper performance of the nitrogen removal units in the sludge line, operational strategies focused on decreasing the organic matter concentration of the THP / AD effluents should be implemented. Mitigation of the ammonia inhibitory effect on AD through the improvement of methanogenic activity via bioaugmentation [33] or trace elements addition [34] could be the most effective options to promote the removal of organic matter by the AD itself, while also increasing biogas production. Moreover, this operational strategy would not require the implementation of additional treatment units. Ammonia inhibitory effects could also be overcome by increasing the SRT of the AD to reach a trade-off between the biogas production rate and the effluent quality [35].

The decrease of the organic matter in the THP / AD effluents could be directly achieved through an aerobic or anaerobic biological pretreatment. The installation of an aerobic pretreatment unit would have no impact on overall aeration requirements since organic matter would be aerobically degraded and ammonia would be removed via PN/A processes, as happens in the single-stage PN/A units; however, in this case, organic matter would be degraded prior to nitrogen removal and not simultaneously. If an anaerobic pretreatment system is applied, the energy balance will improve since the organic matter would generate biogas rather than consume energy due to aeration requirements, thus reducing operating costs. Regarding capital costs, if the nitrogen removal unit was already installed in the WWTP sludge line, the implementation of pretreatment units would increase such costs. However, if a nitrogen removal unit were to be installed, its implementation in conjunction with a pretreatment system would allow for operation at a higher nitrogen loading rate. Consequently, the volume required by this unit would be lower. On the one hand, there would be an increase in capital costs associated with the implementation of the pretreatment unit; on the other hand, there would be a decrease in capital costs associated with the smaller size required by the PN/A system. Considering both operating and capital costs, in the case of installing new nitrogen removal units, the economic analysis (calculation description is provided in Supplementary Material) shows that the application of an aerobic pretreatment system would be advisable for WWTP sizes larger than 500,000 equivalent inhabitants (Figure 2). Nevertheless, when the sidestream nitrogen removal technologies are already installed (nowadays, there are at least 17 WWTPs with both thermal treatment and nitrogen removal units in their sludge line), the implementation of this pretreatment is not economically advantageous, and it would only be justified if the organic matter did not allow for a stable operation of the PN/A system. In the case of anaerobic pretreatment, its application would be advisable both for new or already installed nitrogen removal systems (Figure 2). 


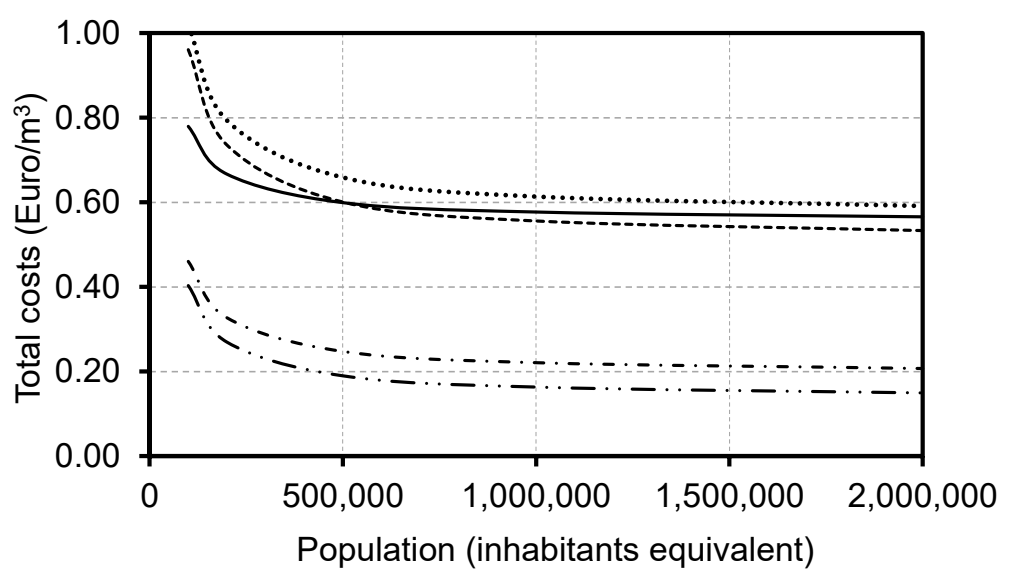

Figure 2. Total costs of treating the THP/AD effluents to remove both organic matter and ammonium ( — without pretreatment; .......... existing facility + aerobic pretreatment; - - - new facility + aerobic pretreatment; $-\cdot-$ existing facility + anaerobic pretreatment; $-\cdots-$ new facility + anaerobic pretreatment).

\section{Application of Anammox-Based Processes in the Mainstream}

Implementations of anammox processes in the sludge line have been successful in reducing operating costs [7]. Considering that the sludge line only contains around $20 \%$ of the nitrogen load entering the WWTP, it would be expected that the application of anammox-based processes in the mainstream would have a notable impact on reducing these treatment costs as well [20]. For this reason, in the last decade, efforts have been made to perform PN/A processes under mainstream conditions such that the resulting effluent meets the disposal standards. This objective, however, has yet to be achieved, in part because of the difficulties in avoiding NOB proliferation and in keeping the nitritation process stable [16].

Until recently, in view of the lower oxygen affinity of $\mathrm{NOB}$ versus $\mathrm{AOB}$, the accepted strategy was to operate the system at low $\mathrm{DO}$ concentrations in order to give $\mathrm{AOB}$ a competitive advantage over NOB. However, Wett et al. [36] observed that this strategy was not suitable in the long term since under mainstream conditions, NOB with a high affinity for oxygen are developed under oxygen-limiting conditions. In addition, in the case of mainstream single-stage PN/A systems, the suppression of NOB activity is challenging because the low $\mathrm{DO}$ that is imposed to maintain the balance between $\mathrm{AOB}$ and anammox bacteria activities favors NOB proliferation $[37,38]$. Thus, maintaining a stable nitritation process in single-stage PN/A systems operated at mainstream conditions requires complex control strategies based on the combination of several parameters such as the SRT of each population, the DO level, alternative aerobic and anoxic periods, among others [39-41]. Moreover, these control strategies must not only suppress NOB proliferation but also manage fluctuations of both the flow rate and the characteristics of incoming wastewater [42]. As an alternative, the use of two-stage nitrogen removal systems can provide greater operational flexibility than that of single-stage systems, achieving a stable PN process under mainstream conditions with easily implemented operational strategies [43,44].

Given the difficulty of maintaining the stability of the mainstream PN process, the oxidation of $50 \%$ of ammonium to nitrate and its subsequent partial denitrification to nitrite by adding organic matter was recently proposed as an alternative route to the generation of the required nitrite for the anammox process $[45,46]$. For this strategy to succeed, the $\mathrm{COD} / \mathrm{N}$ ratio of the influent should be around $2-3 \mathrm{~g} / \mathrm{g}$, since higher ratios would promote total denitrification while lower ratios would not be enough to reduce all nitrate to nitrite [6]. Despite promising results from the combination of partial denitrification and anammox processes at a laboratory scale, obtaining an influent with the required COD/N ratio seems to be the most critical challenge for the application of partial denitrification at full scale [47]. Moreover, the combination of partial denitrification and anammox processes 
is energetically less favorable than the combination of PN/A processes in the removal of nitrogen because a fraction of the ammonium would be oxidized into nitrate instead of nitrite (higher oxygen consumption), and a fraction of the organic matter would be consumed to reduce nitrate to nitrite (lower biogas production) [6].

The literature shows that PN/A processes, and more precisely, the nitritation stage, operate adequately at high nitrogen concentrations and/or high temperatures but not at low concentrations and temperatures lower than $20^{\circ} \mathrm{C}$, as those usually found for sewage [15]. Therefore, instead of putting efforts into designing complex control systems to operate the processes under conditions that are unfavorable for them, the way forward is perhaps in promoting operating conditions that are conducive to them. If we assume as a baseline that $80 \%$ of nitrogen arriving at WWTPs is present in the waterline and that the remaining $20 \%$ is in the sludge line, where PN/A processes are easily applicable, the following three operating strategies can be proposed to remove nitrogen in urban WWTPs through anammox-based processes (Figure 3).

(a)

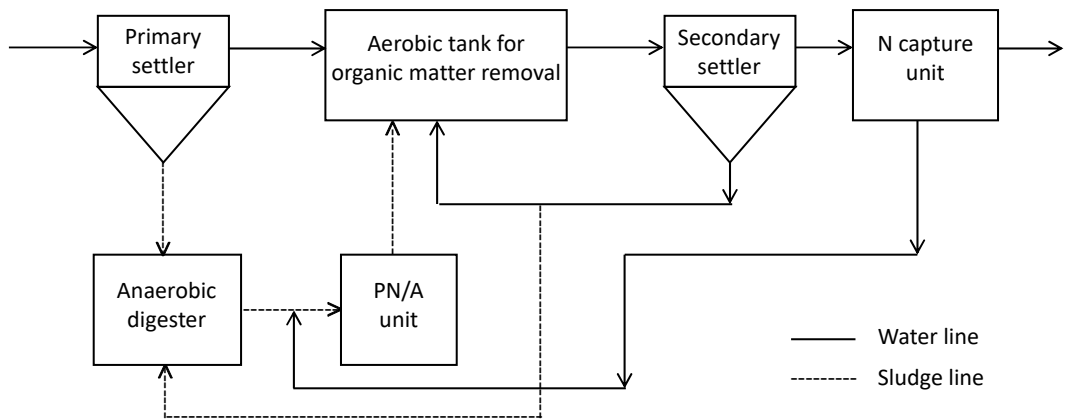

(b)

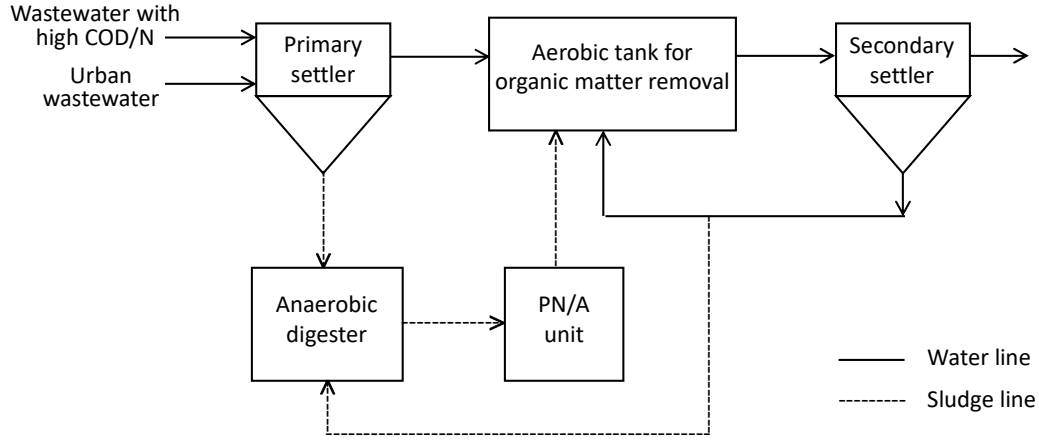

(c)

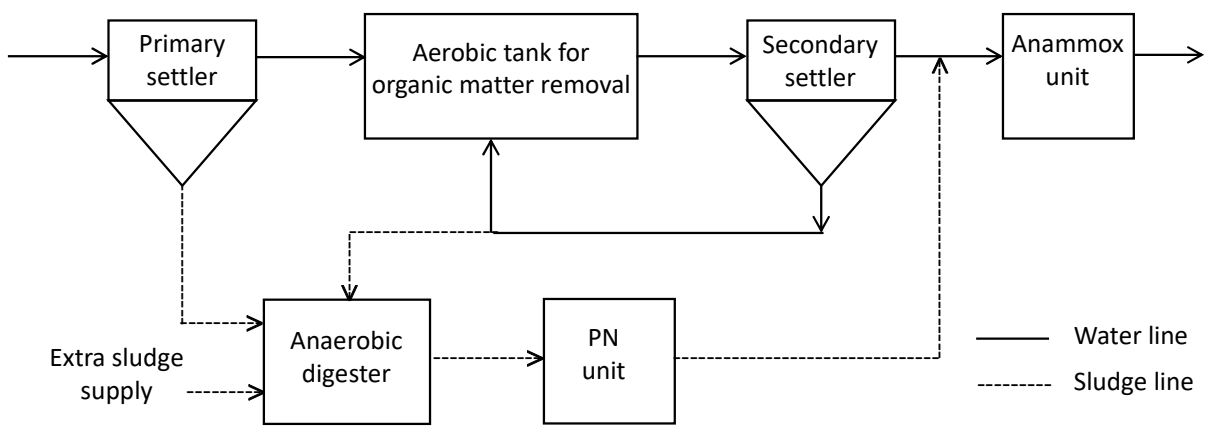

Figure 3. Cont. 
(d)

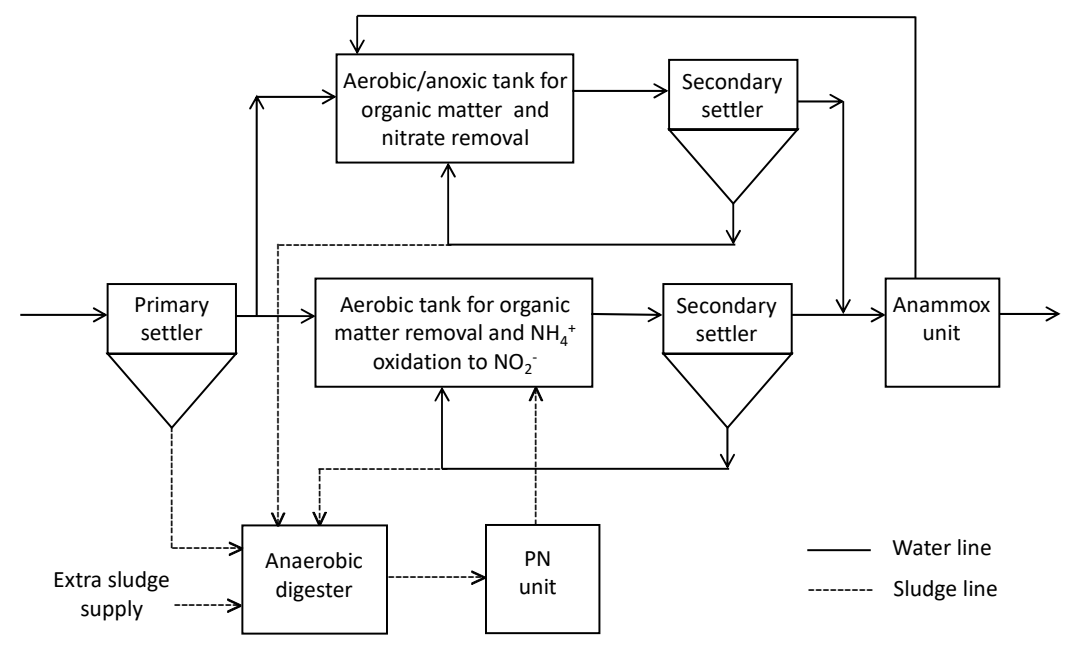

Figure 3. Possible operating strategies to remove nitrogen in urban WWTPs using anammox-based processes: (a) Divert more nitrogen to the sludge line to remove it by the PN/A processes: capture of ammonia by physical/chemical technologies; (b) divert more nitrogen to the sludge line to remove it by the PN/A processes: ammonia bioaccumulation; (c) carry out PN in the sludge line and anammox process in the water line; (d) bioaugmentation of AOB from the sludge line.

\subsection{Divert More Nitrogen to the Sludge Line for Its Removal by the PN/A Processes}

In the same way that organic matter is diverted to the sludge line to improve the WWTP energy balance, ammonium could be captured from the water line and sent to the sludge line as a concentrated stream to be treated by the PN/A processes (Figure 3a). Among the many different physical or chemical technologies that have been proposed to capture ammonium, adsorption through zeolites and membrane filtration are the most noteworthy $[48,49]$. However, these capture processes still have some drawbacks hindering their full-scale implementation such as the need for zeolite regeneration, and in the case of the membrane processes, their power requirements and membrane fouling [50,51]. To avoid these drawbacks, the application of bioaccumulation has been considered. One bioaccumulation strategy that has raised interest in recent years is the use of microalgae, which, once they have captured ammonia for growth, could be co-digested with the WWTP sludge to increase biogas production and release the captured ammonia in the sludge line. Although there have been successful applications of microalgae-based systems to remove nitrogen from the mainstream of WWTPs, this alternative has limited applicability given the large area of land required [52]. Heterotrophic bacteria could replace microalgae in carrying out nitrogen bioaccumulation. For this strategy to succeed, the wastewater $\mathrm{COD} / \mathrm{N}$ ratio should be increased from typical values of around $11-20 \mathrm{~g} / \mathrm{g}$, so that the ammonium can be removed through its assimilation by the heterotrophic bacteria [53]. This requirement could be achieved through the joint management of the organic fraction of municipal solid waste (OFMSW) and urban wastewater (Figure 3b). The OFMSW could be shredded in homes and sent to the WWTP through the sewer, avoiding transport costs. The particulate fraction of the organic matter would be separated in the primary decanter towards the anaerobic digester, while the soluble fraction could be treated in high-load units in order to maximize the generation of sludge and thus promote the assimilation of ammonia as well as minimize oxygen consumption. The sludge generated would be diverted to the anaerobic digester and the captured ammonium would be released in the sludge line. Since the OFMSW has a high COD/N ratio, biogas production in the WWTP would be enhanced, which would offset the increase in aeration costs in the mainstream. Moreover, the additional input of ammonia from OFMSW would almost be negligible, as would be the oxygen consumption associated with its removal. Based on mass balance analyses similar to those performed by Morales et al. [20] and taking into account the characterization of the OFMSW provided by Moñino et al. [54], the joint management 
of OFMSW and sewage would increase the nitrogen load in the sludge line from $20 \%$ to $31 \%$. Accordingly, most of the nitrogen would remain in the mainstream where the conditions are not favorable for the application of PN/A processes. Under these conditions, and considering there was no additional nitrogen removal in the mainstream, the WWTP inlet ammonia concentration would have to be lower than $14 \mathrm{mg} \mathrm{NH}_{4}{ }^{+} \mathrm{N} / \mathrm{L}$ to meet the discharge requirement of $10 \mathrm{mg} \mathrm{N} / \mathrm{L}$ (typical limit in the EU for sensitive areas) (Figure 4). Considering a typical inlet ammonia concentration of $50 \mathrm{mg} \mathrm{NH}_{4}{ }^{+} \mathrm{N} / \mathrm{L}$, it would be necessary to divert at least $90 \%$ of the inlet nitrogen load to the sludge line in order to fulfil the discharge standard. Diverting such a fraction would probably require the use of reverse osmosis membranes in the mainstream, which could be justified only in the case of water reuse [55].

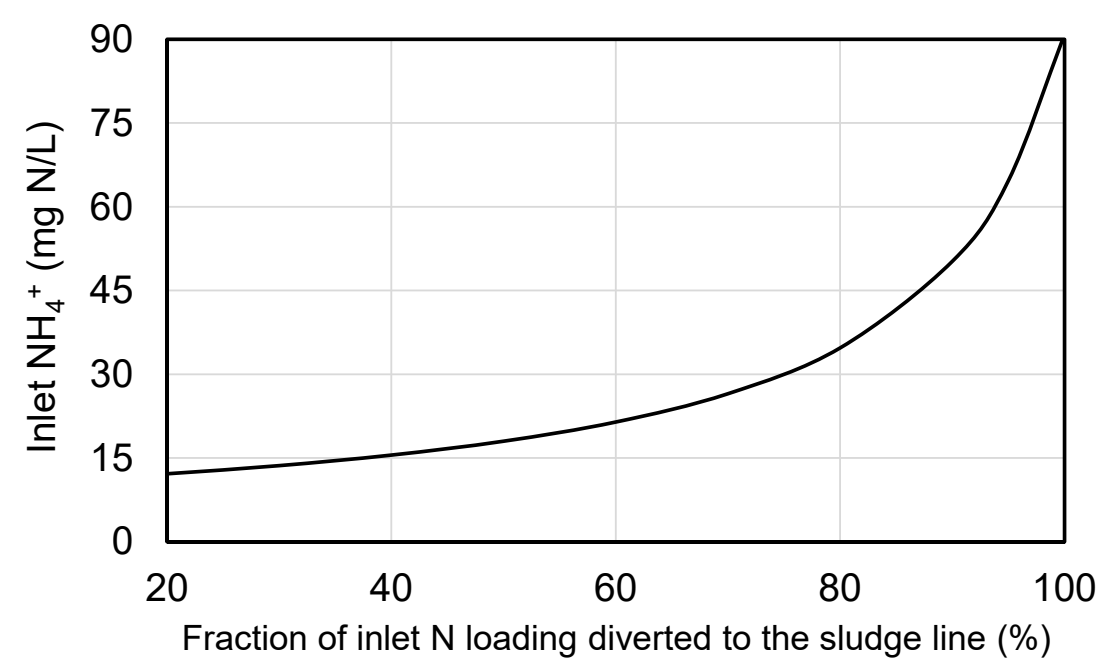

Figure 4. Minimum fraction of the WWTP inlet nitrogen load that should be present in the sludge line to fulfil a discharge requirement of $10 \mathrm{mg} \mathrm{N} / \mathrm{L}$ for the WWTP layout shown in Figure 3a,b.

\subsection{Carry out PN in the Sludge Line and Anammox Process in the Water Line}

A stable performance of the PN process is easily achieved under sludge line conditions [56,57], while the anammox process can be successfully applied under mainstream conditions $[58,59]$. Therefore, nitrite generation could be promoted in the sludge line by adding an alkalinity source to oxidize all the ammonium to nitrite. The sludge line stream containing nitrite would be added to the mainstream once the organic matter has been removed to carry out the anammox process (Figure 3c). Since the nitrogen load of the sludge line is $20 \%$ of the total nitrogen received by the WWTP, the nitrite generated would not be enough to remove all the ammonia from the mainstream. This nitrite deficit could be overcome by increasing the nitrogen load in the sludge line. For this, sludge coming from neighboring WWTPs could be supplied to the sludge anaerobic digesters. The higher ammonia input to the WWTP would bring with it two issues: (1) a higher energy requirement for ammonia removal that could be offset by a higher biogas production, and (2) an increase in the nitrogen concentration of the mainstream, making the discharge limit more difficult to achieve. Considering the nitrogen fluxes of both sludge and water lines and the stoichiometry of the anammox process, this operating strategy would meet the discharge requirements only when the sewage ammonium concentration is lower than $49 \mathrm{mg} \mathrm{NH}_{4}{ }^{+}-\mathrm{N} / \mathrm{L}$ (Figure 5). 


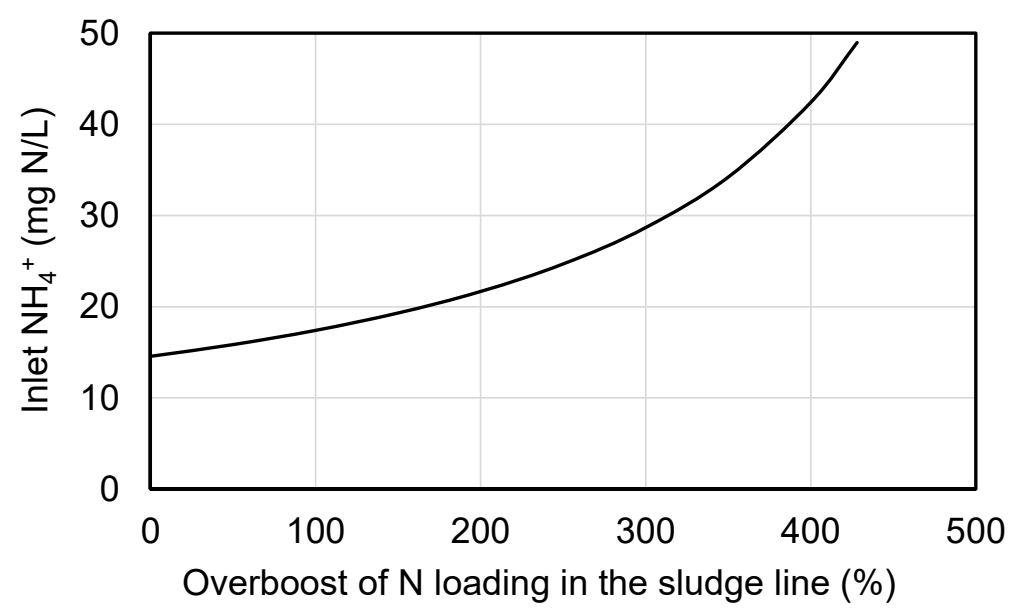

Figure 5. Overboost of the nitrogen load in the sludge line required to fulfil a discharge requirement of $10 \mathrm{mg} \mathrm{N} / \mathrm{L}$ for the WWTP layout shown in Figure 3c.

\subsection{Bioaugmentation of $A O B$ from the Sludge Line}

In order to promote the growth of $\mathrm{AOB}$ over $\mathrm{NOB}$ and to overcome the low growth rate of anammox bacteria under mainstream conditions, the excess of $\mathrm{AOB}$ and anammox bacteria generated in the sludge line could be transferred to the waterline. This bioaugmentation strategy was already applied by Wett et al. [36,40] to the operation of single-stage nitrogen removal systems where the two biomasses were segregated between granules (anammox) and flocs (AOB). Because of the density differences between the two kinds of aggregates, hydrocyclones promote the retention of the anammox biomass and the wash-out of AOB and NOB. However, these hydrocyclones also partially retain NOB and promote their enrichment inside the system, making the control of the system's stability very complex [60]. This incompatibility between maintaining long SRTs to ensure adequate activity of anammox biomass and preventing NOB proliferation was also reported for single-stage PN/A systems using biofilms or granules where $\mathrm{AOB}$ and anammox bacteria grow together [37,61]. Finally, maintaining long SRTs under mainstream conditions also favors the proliferation of complete ammonia-oxidizing bacteria (comammox) [62].

Bioaugmentation could be carried out through periodic biomass exchange between water and sludge lines to avoid mainstream NOB proliferation [42,63]. This strategy relies on promoting the decay of the NOB generated in the mainstream by subjecting them to unfavorable growth conditions (high concentrations of $\mathrm{HNO}_{2}$ and /or $\mathrm{NH}_{3}$ ) in the sludge line $[64,65]$. To obtain total repression of NOB, their net growth in the system must be zero; that is, their decay in the sludge line must counteract their growth in the water line (1):

$$
\mu_{20}{ }^{\circ} \mathrm{C} \cdot \mathrm{SRT}_{\text {mainstream }}=\mathrm{b}_{30}{ }^{\circ} \mathrm{C} \cdot \mathrm{SRT}_{\text {sludge line }}
$$

Taking into account the values of the growth and decay rates reported for NOB by the West Models Guide [66], and a possible operating range of DO concentration in the mainstream of $0.3-2.0 \mathrm{mg} \mathrm{O}_{2} / \mathrm{L}$, Equation (1) would be fulfilled for a sludge line with an SRT 3.2 to 6.9 times higher than the SRT in the mainstream. Considering a biomass concentration factor of 10 from the mainstream to the sludge line, a sludge line tank with a volume of $0.32-0.69$ times the volume of the aerobic tank would be necessary in order to provide enough time for the NOB population to decay. Therefore, this strategy is limited by the availability of land on which to implement a larger tank and the capital costs involved.

If $\mathrm{PN}$ and anammox processes are carried out in separate units, the operating conditions applied to $\mathrm{AOB}$ and $\mathrm{NOB}$ could be more strictly controlled without compromising the retention of anammox bacteria under mainstream conditions. The nitritation reactor would be continuously inoculated, with $\mathrm{AOB}$ coming from the sludge line, and depending on the wastewater temperature, specific conditions for both SRT and DO concentration 
would be imposed to avoid NOB proliferation. The operating conditions imposed must not only prevent the development of new NOB but also limit the activity of NOB present in the wastewater itself [67]. Taking into account the kinetics of NOB [66] and the inlet concentration of these microorganisms $(0.04 \mathrm{mg}$ VSS/L, [67]), it is possible to define operating conditions that limit nitrate concentration to acceptable values so as to maintain effluent quality (Figure 6).

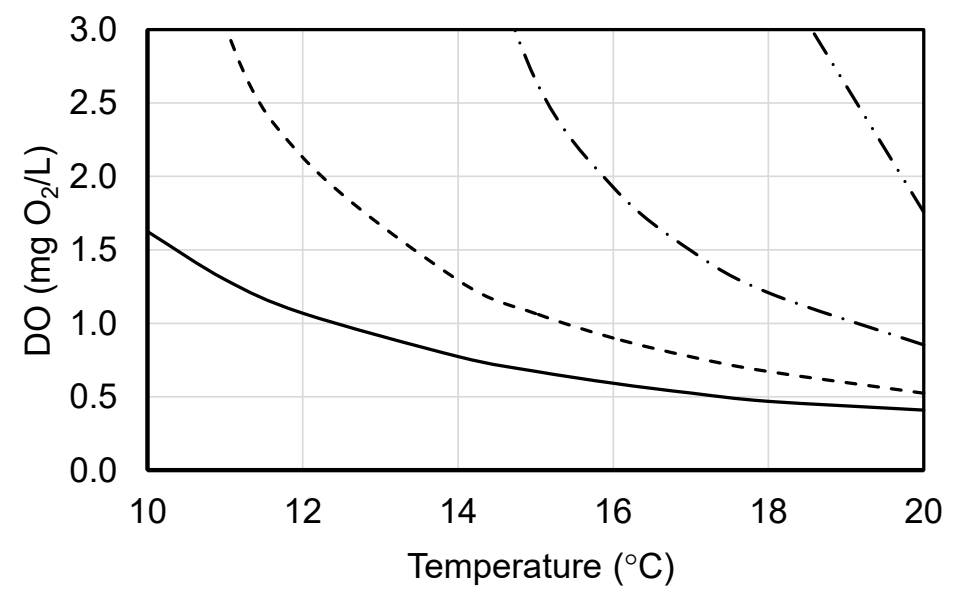

Figure 6. Dissolved oxygen (DO) concentrations that limit the nitrate concentration in the effluent to $1 \mathrm{mg} \mathrm{NO}_{3}{ }^{-}-\mathrm{N} / \mathrm{L}$, depending on the SRT applied and the wastewater temperature (SRT: - $3 \mathrm{~d}$, $---2.5 \mathrm{~d},-\cdot-2 \mathrm{~d},-\cdots-1.6 \mathrm{~d}$ ). (A nitrate concentration of $1 \mathrm{mg} \mathrm{NO}_{3}{ }^{-} \mathrm{N} / \mathrm{L}$ was arbitrarily taken since it is sufficiently low to have a minimal impact on the quality of the effluent).

A possible strategy to carry out the AOB bioaugmentation in the mainstream relies on oxidizing all the ammonium present in the sludge line to nitrite. The nitrite together with the AOB would then be added to an aerobic system where a fraction of the primary decanter effluent would be treated to remove organic matter and oxidize ammonium to nitrite (Figure 3d). Another aerobic system would treat the remaining fraction of the primary decanter effluent to remove only the organic matter. The splitting of the effluent from the primary decanter would be performed so that by joining the streams treated by both systems, the resulting stream would have an $\mathrm{NO}_{2}{ }^{-}-\mathrm{N} / \mathrm{NH}_{4}{ }^{+}-\mathrm{N}$ ratio of $1.32 \mathrm{~g} / \mathrm{g}$, suitable for feeding the anammox system. When applying a mainstream-splitting operating strategy, control of the oxidized ammonium fraction would not be required to achieve a suitable nitrite/ammonium ratio for the anammox process, but the addition of alkalinity would be necessary when the $\mathrm{NH}_{4}{ }^{+}-\mathrm{N} /$ alkalinity ratio of the wastewater is less than $7.1 \mathrm{~g} / \mathrm{g}$. Aerobic systems treating both fractions of the mainstream would be operated at an SRT of 1.6-3 days. These SRT values would allow for a compromise to be reached between the organic matter removal, the sludge sedimentation properties, and the fraction of COD redirected to the anaerobic sludge digesters [2]. Depending on the SRT applied and the wastewater temperature, the dissolved oxygen concentration would be set according to Figure 6 to prevent the proliferation of AOB in the system where only organic matter is removed as well as to limit the activity of the incoming NOB in the system where ammonium is oxidized. However, the conditions imposed to limit nitrite oxidation could also limit the ammonia oxidation capacity of the reactor, especially during the winter period, resulting in the partial oxidation of ammonia to nitrite. This deficiency would prevent getting a suitable nitrite/ammonium ratio for the anammox process and, therefore, deteriorate the quality of the effluent. The lower temperature means a lower inlet WWTP ammonium concentration to meet the discharge requirements (Figure 7). As shown in Figure $7 \mathrm{a}$, for a temperature of $10{ }^{\circ} \mathrm{C}$ and an SRT of $3 \mathrm{~d}$, this strategy would allow for the treatment of wastewater with a maximum inlet ammonia concentration of around $30 \mathrm{mg} \mathrm{NH}_{4}{ }^{+}-\mathrm{N} / \mathrm{L}$. To overcome the negative effect of decreasing temperature on 
the ammonia oxidation capacity in the mainstream, "extra" AOB can be generated in the sludge line by increasing its nitrogen load. As more AOB are generated in the sludge line, the WWTP could handle higher inlet ammonia concentrations (Figure 7b,c). An overboost in the nitrogen load of the sludge line of $100 \%$ would fulfill the discharge requirements for inlet WWTP ammonium concentrations of around $65 \mathrm{mg} \mathrm{NH}_{4}{ }^{+}-\mathrm{N} / \mathrm{L}$, regardless of the operating temperature.

(a)

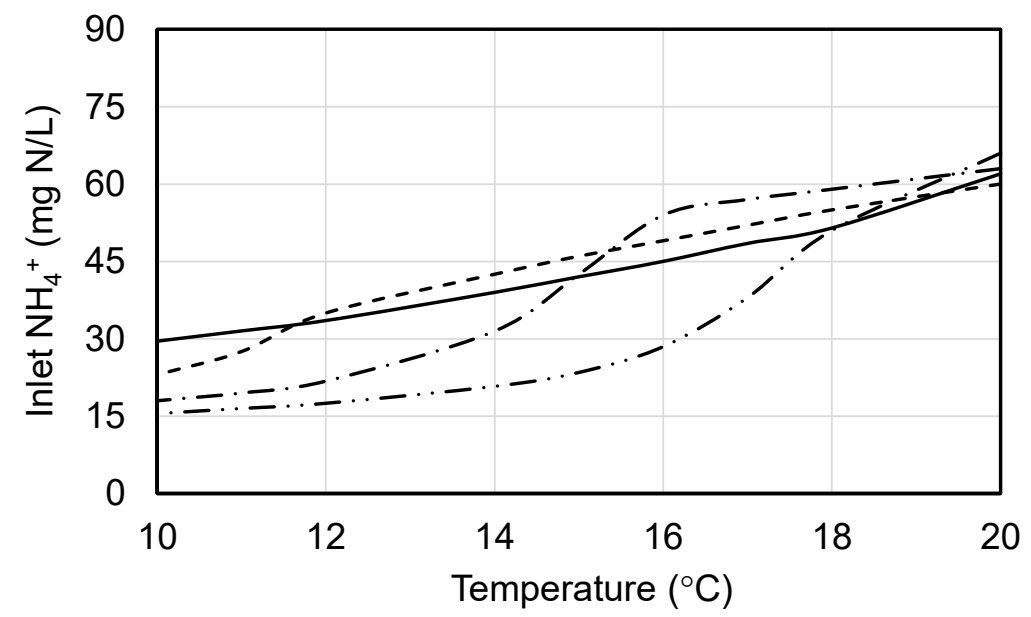

(b)

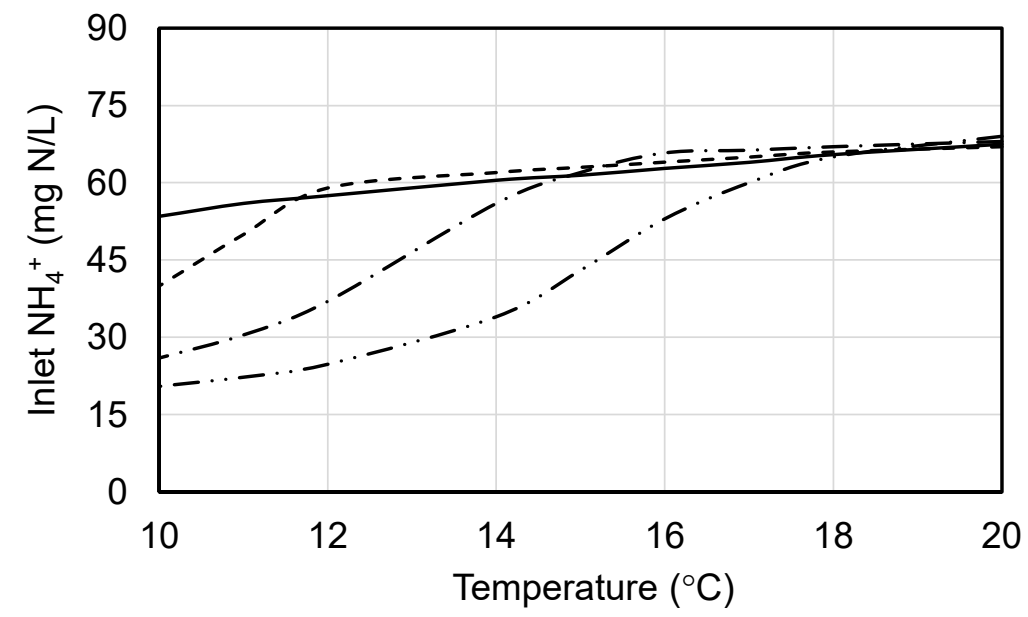

(c)

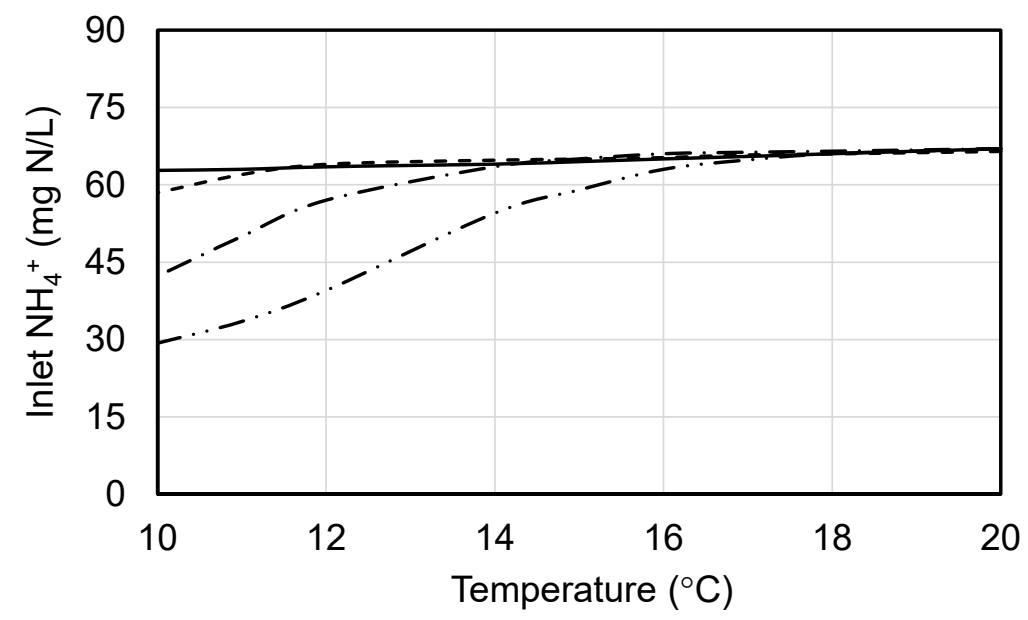

Figure 7. Maximum WWTP inlet ammonia concentration that would fulfill the discharge requirements. Overboost of the nitrogen load in the sludge line: (a) $0 \%$; (b) $50 \%$; (c) $100 \%$ (SRT: — $3 \mathrm{~d}$, $--2.5 \mathrm{~d},-\cdot-2 \mathrm{~d},-\cdots-1.6 \mathrm{~d})$. 
Regarding the implementation of the anammox process under mainstream conditions, the systems based on granular biomass have been shown to maintain stable long-term performance under such conditions because the high settling velocity of the granules allows for good biomass retention $[59,68]$. However, substrate diffusional limitations intrinsic in this type of biomass could cause some of the substrates to remain in the effluent, thus worsening its quality. The anammox granular system must be operated at long SRTs to guarantee very low substrate concentration in the effluent [69]. The anammox process can be started up directly in the mainstream, but the accumulation of the required amount of biomass would take a long time due to the low temperatures and low substrate concentrations of sewage [58]. In order to avoid long start-up periods, the anammox process is usually initiated by using biomass developed in the sludge line. However, the change in the operating conditions from the sludge line to the mainstream can cause a decrease in the size of the granules due to a decline in their extracellular polymer content [70]. This fact could cause a progressive washing out of biomass, and consequently, a loss of the system's operational stability. When mainstream anammox systems are operated, special attention must be paid to the oxygen input from both the influent DO and its transfer from the atmosphere. The presence of DO would favor the oxidation of a fraction of the inlet nitrite to nitrate because of the higher oxygen affinity of NOB, and therefore the effluent quality would deteriorate. In this regard, the previous PN unit should be operated at the lowest possible DO level and the anammox reactors should be covered to avoid oxygen transfer from the atmosphere [69].

In summary, the simplest way to remove nitrogen from urban wastewater by means of PN/A processes would be to promote the PN process in the sludge line and then apply the anammox process in the mainstream. However, given the low fraction of the inlet nitrogen load present in the sludge line, the amount of nitrite generated would not be sufficient to obtain an adequate effluent quality in terms of nitrogen. For this reason, the generation of part of the required nitrite should be carried out in the mainstream, which requires imposing operating conditions that prevent the proliferation of NOB. Such strict operating conditions would entail that AOBs inoculated from the sludge line are unable to produce all the necessary nitrite; thus, the $\mathrm{AOB}$ generation would have to be increased by supplying extra sludge to the anaerobic digesters.

\section{Interactions between AOB and Anammox Bacteria and Others: Are They Useful for Obtaining the Desired Effluent Quality?}

Previous studies on the application of PN/A processes in the mainstream showed difficulties in fulfilling the effluent nitrogen discharge requirements due to the nitrate generated by NOB and anammox bacteria [37,40,61]. For this reason, the possible joint application of partial nitritation or partial nitratation and anammox processes with other processes related to bacteria involved in the nitrogen cycle has been proposed to obtain an effluent with adequate quality for its discharge. Among these processes, it is worth mentioning the heterotrophic denitrification, sulfur-driven denitrification, and denitrification using methane (damo process) [71-73]. However, although the combination of such processes improves nitrogen removal efficiency, it should be noted that the greater the number of processes that are intended to be carried out jointly, the narrower the operating window will be since there are bound to be more stoichiometric constraints. For example, when heterotrophic denitrification is combined with PN/A processes in the same reactor, in addition to controlling the $\mathrm{DO}$ level, the inlet $\mathrm{COD} / \mathrm{N}$ ratio should be maintained at values of around $2 \mathrm{~g} / \mathrm{g}$ in order to achieve a compromise between the nitrogen removal efficiency and oxygen consumption [74]. When partial nitratation is combined with sulfur-driven denitrification and anammox processes, the $\mathrm{H}_{2} \mathrm{~S}-\mathrm{S} / \mathrm{NO}_{3}{ }^{-}-\mathrm{N}$ and $\mathrm{NO}_{3}{ }^{-}-\mathrm{N} / \mathrm{NH}_{4}{ }^{+}-\mathrm{N}$ ratios should be maintained as close as possible to $0.57 \mathrm{~g} / \mathrm{g}$ and $1.32 \mathrm{~g} / \mathrm{g}$, respectively, in order to optimize nitrogen removal efficiency [75]. Therefore, control of the operating conditions that allow for the maintenance of the necessary balance between all the processes involved will be more difficult. This low operational stability of combined processes could limit their 
application, and facilities that use them are not currently implemented in urban WWTPs at full scale [76].

As discussed in the previous sections, carrying out the partial nitritation and anammox processes in separate units would allow for the application of relatively simple operational strategies to avoid the proliferation of NOB. However, if the input ammonium concentration were to exceed $60-65 \mathrm{mg} \mathrm{NH}_{4}{ }^{+}-\mathrm{N} / \mathrm{L}$, it would be challenging to meet the discharge limit of $10 \mathrm{mg} \mathrm{N} / \mathrm{L}$, mainly because of the nitrate generated by the anammox process itself. For this reason, when necessary, a process to remove excess nitrate should be promoted in order to adjust effluent quality. For practical reasons, processes involving fast-growing bacteria such as heterotrophic denitrifiers are preferred for a rapid response, and the use of slow-growing bacteria such as those involved in the damo process and sulfur-driven denitrification should be ruled out. Furthermore, the problematic management of methane (in the damo process) and the generation of sulfate (in the case of the sulfur-driven denitrification) could cause a deterioration of the effluent quality [77,78].

Since nitrate would be removed only when the effluent does not reach the discharge limit, implementing an occasional post-treatment unit to carry out heterotrophic denitrification may not be the most cost-effective option. In this sense, the removal of excess nitrate in the anammox reactor itself could be an interesting alternative to save capital costs. Organic matter could be added to the anammox reactor and be used by the anammox bacteria themselves or the heterotrophic denitrifying bacteria that are associated with them to remove excess nitrate $[79,80]$. The organic matter could be provided from an external source (methanol or acetic acid), or even through a by-pass of the stream coming from the primary decanter, the latter being a cheaper option. However, this solution would have the disadvantage of increasing the ammonium level in the effluent if the efficiency of ammonium conversion into nitrite is not adjusted. To use the organic matter from sewage, nitrite production should be maximized in the PN unit to cope with the additional ammonium supplied to the anammox unit [81]. The combination of the anammox process and heterotrophic denitrification has been studied repeatedly; however, the COD/N ratio that maximizes the nitrogen removal efficiency without compromising the stability of the anammox process remains unclear [79]. In any case, an excessive COD/ $\mathrm{N}$ ratio should be avoided since it could lead to excessive consumption of nitrite by denitrifying bacteria or even to the presence of organic matter in the effluent [82]. For this reason, it is necessary to have rigorous control of the dose of organic matter in order to obtain the required effluent quality.

Due to the complexity of dosing an optimal quantity of organic matter so as not to compromise the quality of the effluent, the safest alternative would be to take part of the effluent from the anammox system and recirculate it to the aerobic system, where only the removal of organic matter takes place (Figure 3d). At the head of this reactor, it might be possible to operate a chamber under anoxic or aerobic conditions, depending on the nitrate level of the anammox reactor effluent. In this way, the removal of excess nitrate would be guaranteed by using both organic matter of the wastewater itself and heterotrophic bacteria present in the aerobic tank without compromising either the performance of the anammox reactor or the effluent quality. Finally, the fraction of the stream to be recirculated would be relatively low as it would only be focused on refining the effluent and not on removing most of the nitrogen.

\section{Conclusions}

- The $\mathrm{COD}_{\text {biodegradable }} / \mathrm{N}$ ratio at the inlet of single-stage nitrogen removal systems treating THP/AD effluents should be maintained below 0.5 to avoid losing operational stability. For this purpose, applying an anerobic pretreatment seems to be a viable option from an economic perspective.

- When single-stage nitrogen removal systems are applied under mainstream conditions, maintaining the stability of the nitritation process requires complex control strategies and adequate effluent quality is not guaranteed. In this sense, promoting the growth 
of AOB in the sludge line by supplying extra sludge to the anaerobic digesters in order to carry out their bioaugmentation in the mainstream and subsequently applying the anammox process could be a feasible strategy for achieving autotrophic nitrogen removal from urban wastewater.

- Combining PN/A with other biological processes can be used to adjust excess nitrate to meet discharge requirements. However, the more processes taking place simultaneously, the more difficult it will be to balance them. A simple way to remove excess nitrate would be to partially recirculate the WWTP effluent to the unit where organic matter is removed and promote heterotrophic denitrification by implementing an anoxic chamber.

Supplementary Materials: The following are available online at https:/ / www.mdpi.com/article/10 .3390/pr9081334/s1, Description of calculations: (a) Calculation of the effect of $\mathrm{NH}_{3}$ presence on the effluent quality of an anaerobic sludge digester; (b) Calculation of treatment costs for removing both organic matter and ammonia from supernatant of anaerobic sludge digester; (c) Calculation of the maximum ammonia inlet concentration to fulfill the discharge nitrogen limit.

Author Contributions: Conceptualization, A.P., J.R.V.-P., and J.L.C.; methodology, D.C. and J.L.C.; writing-original draft preparation and performed the calculations, J.L.C.; data analysis, A.P., J.R.V.P., and D.C.; writing-review and editing, A.P. and D.C. All authors contributed to the writing and proofreading of the paper. All authors have read and agreed to the published version of the manuscript.

Funding: This research was funded by the Chilean Government through the Projects ANID/FONDECYT/1200850 and CRHIAM Centre grant number ANID/FONDAP/15130015. FCC Aqualia, S.A. as coordinator of the LIFE ZERO WASTE WATER consortium would like to thank the European Commission for its support through LIFE financial instrument LIFE19ENV/ES/000631.

Acknowledgments: The authors thank Jacques Dumais for his support in reviewing the language.

Conflicts of Interest: J.R.V.-P. is employed by the company FCC Aqualia, S.A. The remaining authors declare that the research was conducted in the absence of any commercial or financial relationships that could be construed as a potential conflict of interest.

\section{References}

1. Gu, Y.; Li, Y.; Li, X.; Luo, P.; Wang, H.; Robinson, Z.P.; Wang, X.; Wu, J.; Li, F. The feasibility and challenges of energy self-sufficient wastewater treatment plants. Appl. Energy 2017, 204, 1463-1475. [CrossRef]

2. Sancho, I.; Lopez-Palau, S.; Arespacochaga, N.; Cortina, J.L. New concepts on carbon redirection in wastewater treatment plants: A review. Sci. Total. Environ. 2019, 647, 1373-1384. [CrossRef] [PubMed]

3. Taboada-Santos, A.; Rivadulla, E.; Paredes, L.; Carballa, M.; Romalde, J.; Lema, J.M. Comprehensive comparison of chemically enhanced primary treatment and high-rate activated sludge in novel wastewater treatment plant configurations. Water Res. 2020, 169, 115258. [CrossRef] [PubMed]

4. Cao, S.; Lu, D.; Phua, K.; Yan, W.; Le, C.; Tao, G.; Zhou, Y. Organics transformation and energy production potential in a high rate A-stage system: A demo-scale study. Bioresour. Technol. 2020, 295, 122300. [CrossRef]

5. Carrera, J.; Vicent, T.; Lafuente, J. Effect of influent COD/N ratio on biological nitrogen removal (BNR) from high-strength ammonium industrial wastewater. Process Biochem. 2004, 39, 2035-2041. [CrossRef]

6. Zhang, M.; Wang, S.; Ji, B.; Liu, Y. Towards mainstream deammonification of municipal wastewater: Partial nitrification-anammox versus partial denitrification-anammox. Sci. Total. Environ. 2019, 692, 393-401. [CrossRef]

7. Siegrist, H.; Salzgeber, D.; Eugster, J.; Joss, A. Anammox brings WWTP closer to energy autarky due to increased biogas production and reduced aeration energy for N-removal. Water Sci. Technol. 2008, 57, 383-388. [CrossRef]

8. Nsenga Kumwimba, M.; Lotti, T.; Şenel, E.; Li, X.; Suanon, F. Anammox-based processes: How far have we come and what work remains? A review by bibliometric analysis. Chemosphere 2020, 238, 124627. [CrossRef] [PubMed]

9. Izadi, P.; Izadi, P.; Eldyasti, A. Towards mainstream deammonification: Comprehensive review on potential mainstream applications and developed sidestream technologies. J. Environ. Manag. 2021, 279, 111615. [CrossRef]

10. Zhang, Q.; De Clippeleir, H.; Su, C.; Al-Omari, A.; Wett, B.; Vlaeminck, S.E.; Murthy, S. Deammonification for digester supernatant pretreated with thermal hydrolysis: Overcoming inhibition through process optimization. Appl. Microbiol. Biotechnol. 2016, 100, 5595-5606. [CrossRef] 
11. Zhang, Q.; Vlaeminck, S.E.; DeBarbadillo, C.; Su, C.; Al-Omari, A.; Wett, B.; Pümpel, T.; Shaw, A.; Chandran, K.; Murthy, S.; et al. Supernatant organics from anaerobic digestion after thermal hydrolysis cause direct and/or diffusional activity loss for nitritation and anammox. Water Res. 2018, 143, 270-281. [CrossRef]

12. Ochs, P.; Martin, B.D.; Germain, E.; Stephenson, T.; van Loosdrecht, M.; Soares, A. Ammonia removal from thermal hydrolysis dewatering liquors via three different deammonification technologies. Sci. Total. Environ. 2021, 755, 142684. [CrossRef]

13. Li, X.; Klaus, S.; Bott, C.; He, Z. Status, Challenges, and Perspectives of Mainstream Nitritation-Anammox for Wastewater Treatment. Water Environ. Res. 2018, 90, 634-649. [CrossRef]

14. Ma, W.-J.; Li, G.-F.; Huang, B.-C.; Jin, R.-C. Advances and challenges of mainstream nitrogen removal from municipal wastewater with anammox-based processes. Water Environ. Res. 2020, 92, 1899-1909. [CrossRef]

15. Qiu, S.; Li, Z.; Hu, Y.; Shi, L.; Liu, R.; Shi, L.; Chen, L.; Zhan, X. What's the best way to achieve successful mainstream partial nitritation-anammox application? Crit. Rev. Environ. Sci. Technol. 2020, 51, 1045-1077. [CrossRef]

16. Agrawal, S.; Seuntjens, D.; Cocker, P.D.; Lackner, S.; Vlaeminck, S.E. Success of mainstream partial nitritation/anammox demands integration of engineering, microbiome and modeling insights. Curr. Opin. Biotechnol. 2018, 50, 214-221. [CrossRef]

17. Wu, G.; Zhang, T.; Gu, M.; Chen, Z.; Yin, Q. Review of characteristics of anammox bacteria and strategies for anammox start-up for sustainable wastewater resource management. Water Sci. Technol. 2020, 82, 1742-1757. [CrossRef]

18. Cao, Y.; Kwok, B.H.; van Loosdrecht, M.C.M.; Daigger, G.; Png, H.Y.; Long, W.Y.; Eng, O.K. The influence of dissolved oxygen on partial nitritation/anammox performance and microbial community of the $200,000 \mathrm{~m}^{3} / \mathrm{d}$ activated sludge process at the Changi water reclamation plant (2011 to 2016). Water Sci. Technol. 2018, 78, 634-643. [CrossRef]

19. Lackner, S.; Gilbert, E.M.; Vlaeminck, S.E.; Joss, A.; Horn, H.; van Loosdrecht, M.C.M. Full-scale partial nitritation/anammox experiences-An application survey. Water Res. 2014, 55, 292-303. [CrossRef]

20. Morales, N.; Val del Río, Á.; Vázquez-Padín, J.R.; Méndez, R.; Mosquera-Corral, A.; Campos, J.L. Integration of the Anammox process to the rejection water and main stream lines of WWTPs. Chemosphere 2015, 140, 99-105. [CrossRef]

21. Barber, W.P.F. Thermal hydrolysis for sewage treatment: A critical review. Water Res. 2016, 104, 53-71. [CrossRef]

22. Cano, R.; Pérez-Elvira, S.I.; Fdz-Polanco, F. Energy feasibility study of sludge pretreatments: A review. Appl. Energy 2015, 149, 176-185. [CrossRef]

23. Figdore, B.A.; Wett, B.; Hell, M.; Murthy, S. Deammonification of Dewatering Sidestream from Thermal Hydrolysis-Mesophilic Anaerobic Digestion Process. Proc. Water Environ. Fed. 2011, 1, 1037-1052. [CrossRef]

24. Figdore, B.; Bowden, G.; Stinson, B.; Wett, B.; Hell, M.; Bailey, W.; Carr, J.; Der Minassian, R.; Murthy, S. Treatment of Dewatering Sidestream from a Thermal Hydrolysis-Mesophilic Anaerobic Digestion Process with a Single-Sludge Deammonification Process. Proc. Water Environ. Fed. 2011, 2011, 249-264. [CrossRef]

25. Lemaire, R.; Veuillet, F.; Bausseron, A.; Chastrusse, S.; Monnier, R.; Christensson, M.; Zhao, H.W.; Thomson, C.; Ochoa, J. ANITAMox deammonification process for COD-rich and THP reject water. Proc. Water Environ. Fed. 2015, 16, 3266-3279. [CrossRef]

26. Driessen, W.; Van Veldhoven, J.T.A.; Janssen, M.P.M.; Van Loosdrecht, M.C.M. Treatment of sidestream dewatering liquors from thermally hydrolised and anaerobically digested biosolids. Water Pract. Technol. 2020, 15, 142-150. [CrossRef]

27. Jiang, Y.; McAdam, E.; Zhang, Y.; Heaven, S.; Banks, C.; Longhurst, P. Ammonia inhibition and toxicity in anaerobic digestion: A critical review. J. Water Process. Eng. 2019, 32, 100899. [CrossRef]

28. Wilson, C.A.; Tanneru, C.T.; Banjade, S.; Murthy, S.N.; Novak, J.T. Anaerobic Digestion of Raw and Thermally Hydrolyzed Wastewater Solids Under Various Operational Conditions. Water Environ. Res. 2011, 83, 815-825. [CrossRef]

29. Giustinianovich, E.A.; Campos, J.-L.; Roeckel, M.D. The presence of organic matter during autotrophic nitrogen removal: Problem or opportunity? Sep. Purif. Technol. 2016, 166, 102-108. [CrossRef]

30. Gu, Z.; Li, Y.; Yang, Y.; Xia, S.; Hermanowicz, S.W.; Alvarez-Cohen, L. Inhibition of anammox by sludge thermal hydrolysis and metagenomic insights. Bioresour. Technol. 2018, 270, 46-54. [CrossRef]

31. Zhang, D.; Wang, G.; Dai, X. Operation of pilot-scale nitrification-anammox reactors for the treatment of reject-water produced from the anaerobic digestion of thermal hydrolysis-treated sludge. Bioresour. Technol. 2020, 314, 123717. [CrossRef]

32. Xu, Y.; Xu, Y.; Li, T.; Wang, G.; Dai, X. Two-step partial nitrification-anammox process for treating thermal-hydrolysis anaerobic digester effluent: Start-up and microbial characterisation. J. Clean. Prod. 2020, 252, 119784. [CrossRef]

33. Yan, M.; Treu, L.; Campanaro, S.; Tiana, H.; Zhu, X.; Khoshnevisan, B.; Tsapekos, P.; Angelidaki, I.; Fotidis, J.A. Effect of ammonia on anaerobic digestion of municipal solid waste: Inhibitory performance, bioaugmentation and microbiome functional reconstruction. Chem. Eng. J. 2020, 401, 126159. [CrossRef]

34. Molaey, R.; Bayrakdar, A.; Sürmeli, R.O.; Çalli, B. Anaerobic digestion of chicken manure: Mitigating process inhibition at high ammonia concentrations by selenium supplementation. Biomass Bioenergy 2018, 108, 439-446. [CrossRef]

35. Mahdy, A.; Bi, S.; Song, Y.; Qiao, W.; Dong, R. Overcome inhibition of anaerobic digestion of chicken manure under ammoniastressed condition by lowering the organic loading rate. Bioresour. Technol. Rep. 2020, 9, 100359. [CrossRef]

36. Wett, B.; Omari, A.; Podmirseg, S.M.; Han, M.; Akintayo, O.; Gómez Brandón, M.; Murthy, S.; Bott, C.; Hell, M.; Takács, I.; et al. Going for mainstream deammonification from bench to full scale for maximized resource efficiency. Water Sci. Technol. 2013, 68, 283-289. [CrossRef] [PubMed] 
37. Morales, N.; Val del Río, Á.; Vázquez-Padín, J.R.; Méndez, R.; Campos, J.L.; Mosquera-Corral, A. The granular biomass properties and the acclimation period affect the partial nitritation/anammox process stability at a low temperature and ammonium concentration. Process Biochem. 2016, 51, 2134-2142. [CrossRef]

38. Val del Rio, A.; Campos, J.L.; Da Silva, C.; Pedrouso, A.; Mosquera-Corral, A. Determination of the intrinsic kinetic parameters of ammonia-oxidizing and nitrite-oxidizing bacteria in granular and flocculent sludge. Sep. Purif. Technol. 2019, 213, 571-577. [CrossRef]

39. Regmi, P.; Miller, M.W.; Holgate, B.; Bunce, R.; Park, H.; Chandran, K.; Wett, B.; Murthy, S.; Bott, C.B. Control of aeration, aerobic SRT and COD input for mainstream nitritation/denitritation. Water Res. 2014, 57, 162-171. [CrossRef]

40. Wett, B.; Podmirseg, S.M.; Gómez-Brandón, M.; Hell, M.; Nyhuis, G.; Bott, C.; Murthy, S. Expanding DEMON Sidestream Deammonification Technology Towards Mainstream Application. Water Environ. Res. 2015, 87, 2084-2089. [CrossRef] [PubMed]

41. Laureni, M.; Falås, P.; Robin, O.; Wick, A.; Weissbrodt, D.G.; Nielsen, J.L.; Ternes, T.A.; Morgenroth, E.; Joss, A. Mainstream partial nitritation and anammox: Long-term process stability and effluent quality at low temperatures. Water Res. 2016, 101, 628-639. [CrossRef]

42. Qiu, S.; Wang, L.; Chen, Z.; Yang, M.; Yu, Z.; Ge, S. An integrated mainstream and sidestream strategy for overcoming nitrite oxidizing bacteria adaptation in a continuous plug-flow nutrient removal process. Bioresour. Technol. 2021, 319, 124133. [CrossRef]

43. Pedrouso, A.; Val del Río, Á.; Morales, N.; Vázquez-Padín, J.R.; Campos, J.L.; Méndez, R.; Mosquera-Corral, A. Nitrite oxidizing bacteria suppression based on in-situ free nitrous acid production at mainstream conditions. Sep. Purif. Technol. 2017, 186, 55-62. [CrossRef]

44. Chen, Y.; Zhao, Z.; Liu, H.; Ma, Y.; An, F.; Huang, J.; Shao, Z. Achieving stable two-stage mainstream partial-nitrification/anammox (PN/A) operation via intermittent aeration. Chemosphere 2020, 245, 125650. [CrossRef] [PubMed]

45. Ma, B.; Qian, W.; Yuan, C.; Yuan, Z.; Peng, Y. Achieving Mainstream Nitrogen Removal through Coupling Anammox with Denitratation. Environ. Sci. Technol. 2017, 51, 8405-8413. [CrossRef]

46. Cao, S.; Oehmen, A.; Zhou, Y. Denitrifiers in Mainstream Anammox Processes: Competitors or Supporters? Environ. Sci. Technol. 2019, 53, 11063-11065. [CrossRef] [PubMed]

47. Мa, B.; Xu, X.; Wei, Y.; Ge, C.; Peng, Y. Recent advances in controlling denitritation for achieving denitratation/anammox in mainstream wastewater treatment plants. Bioresour. Technol. 2020, 299, 122697. [CrossRef] [PubMed]

48. Robles, Á.; Aguado, D.; Barat, R.; Borrás, L.; Bouzas, A.; Giménez, J.B.; Martí, N.; Ribes, J.; Ruano, M.V.; Serralta, J.; et al. New frontiers from removal to recycling of nitrogen and phosphorus from wastewater in the Circular Economy. Bioresour. Technol. 2020, 300, 122673. [CrossRef]

49. Zhang, X.; Liu, Y. Circular economy-driven ammonium recovery from municipal wastewater: State of the art, challenges and solutions forward. Bioresour. Technol. 2021, 334, 125231. [CrossRef] [PubMed]

50. Wang, S.; Peng, Y. Natural zeolites as effective adsorbents in water and wastewater treatment. Chem. Eng. J. 2010, 156, 11-24. [CrossRef]

51. Xie, M.; Shon, H.K.; Gray, S.R.; Elimelech, M. Membrane-based processes for wastewater nutrient recovery: Technology, challenges, and future direction. Water Res. 2016, 89, 210-221. [CrossRef]

52. Mohsenpour, S.F.; Hennige, S.; Willoughby, N.; Adeloye, A.; Gutierrez, T. Integrating micro-algae into wastewater treatment: A review. Sci. Total. Environ. 2021, 752, 142168. [CrossRef]

53. Winkler, M.K.H.; Straka, L. New directions in biological nitrogen removal and recovery from wastewater. Curr. Opin. Biotechnol. 2019, 57, 50-55. [CrossRef]

54. Moñino, P.; Jiménez, E.; Barat, R.; Aguado, D.; Seco, A.; Ferrer, J. Potential use of the organic fraction of municipal solid waste in anaerobic co-digestion with wastewater in submerged anaerobic membrane technology. Waste Manag. 2016, 56, 158-165. [CrossRef]

55. Verstraete, W.; Vlaeminck, S.E. ZeroWasteWater: Short-cycling of wastewater resources for sustainable cities of the future. Int. J. Sustain. Dev. World Ecol. 2011, 18, 253-264. [CrossRef]

56. Zhang, L.; Yang, J.; Furukawa, K. Stable and high-rate nitrogen removal from reject water by partial nitrification and subsequent anammox. J. Biosci. Bioeng. 2010, 110, 441-448. [CrossRef] [PubMed]

57. López-Palau, S.; Dosta, J.; Pericas, A.; Mata-Álvarez, J. Partial nitrification of sludge reject water using suspended and granular biomass. J. Chem. Technol. Biotechnol. 2011, 86, 1480-1487. [CrossRef]

58. Hendrickx, T.L.G.; Wang, Y.; Kampman, C.; Zeeman, G.; Temmink, H.; Buisman, C.J.N. Autotrophic nitrogen removal from low strength waste water at low temperature. Water Res. 2012, 46, 2187-2193. [CrossRef]

59. Juan-Díaz, X.; Pérez, J.; Carrera, J. Effective dampening of temperature effects in an anammox reactor treating real mainstream wastewater. J. Water Process Eng. 2021, 40, 101853. [CrossRef]

60. Shi, Y.; Wells, G.; Morgenroth, E. Microbial activity balance in size fractionated suspended growth biomass from full-scale sidestream combined nitritation-anammox reactors. Bioresour. Technol. 2016, 218, 38-45. [CrossRef] [PubMed]

61. Trojanowicz, K.; Plaza, E.; Trela, J. Pilot scale studies on nitritation-anammox process for mainstream wastewater at low temperature. Water Sci. Technol. 2016, 73, 761-768. [CrossRef] [PubMed]

62. Cotto, I.; Dai, Z.; Huo, L.; Anderson, C.L.; Vilardi, K.J.; Ijaz, U.; Khunjar, W.; Wilson, C.; De Clippeleir, H.; Gilmore, K.; et al. Long solids retention times and attached growth phase favor prevalence of comammox bacteria in nitrogen removal systems. Water Res. 2020, 169, 115268. [CrossRef] [PubMed] 
63. Peng, L.; Xie, Y.; Van Beeck, W.; Zhu, W.; Van Tendeloo, M.; Tytgat, T.; Lebeer, S.; Vlaeminck, S.E. Return-Sludge Treatment with Endogenous Free Nitrous Acid Limits Nitrate Production and $\mathrm{N}_{2} \mathrm{O}$ Emission for Mainstream Partial Nitritation/Anammox. Environ. Sci. Technol. 2020, 54, 5822-5831. [CrossRef]

64. Wang, Q.; Ye, L.; Jiang, G.; Hu, S.; Yuan, Z. Side-stream sludge treatment using free nitrous acid selectively eliminates nitrite oxidizing bacteria and achieves the nitrite pathway. Water Res. 2014, 55, 245-255. [CrossRef]

65. Duan, H.; Ye, L.; Lu, X.; Yuan, Z. Overcoming Nitrite Oxidizing Bacteria Adaptation through Alternating Sludge Treatment with Free Nitrous Acid and Free Ammonia. Environ. Sci. Technol. 2019, 53, 1937-1946. [CrossRef]

66. DHI. WEST Models Guide. [online] (n.d.) (WEST Models Guide). Available online: https://manuals.mikepoweredbydhi.help/ latest/Cities/TornadoModels/index.htm (accessed on 7 April 2021).

67. Duan, H.; Ye, L.; Wang, Q.; Zheng, M.; Lu, X.; Wang, Z.; Yuan, Z. Nitrite oxidizing bacteria (NOB) contained in influent deteriorate mainstream NOB suppression by sidestream inactivation. Water Res. 2019, 162, 331-338. [CrossRef] [PubMed]

68. Ma, B.; Peng, Y.; Zhang, S.; Wang, J.; Gan, Y.; Chang, J.; Wang, S.; Wang, S.; Zhu, G. Performance of anammox UASB reactor treating low strength wastewater under moderate and low temperatures. Bioresour. Technol. 2013, 129, 606-611. [CrossRef]

69. Díaz, C.; Belmonte, M.; Campos, J.L.; Franchi, O.; Faúndez, M.; Vidal, G.; Argiz, L.; Pedrouso, A.; Val del Rio, A.; Mosquera-Corral, A. Limits of the anammox process in granular systems to remove nitrogen at low temperature and nitrogen concentration. Process Saf. Environ. Prot. 2020, 138, 349-355. [CrossRef]

70. Wang, Y.; Xie, H.; Wang, D.; Wang, W. Insight into the response of anammox granule rheological intensity and size evolution to decreasing temperature and influent substrate concentration. Water Res. 2019, 162, 258-268. [CrossRef] [PubMed]

71. Cao, S.; Du, R.; Zhou, Y. Coupling anammox with heterotrophic denitrification for enhanced nitrogen removal: A review. Crit. Rev. Environ. Sci. Technol. 2020, 1-34. [CrossRef]

72. Rios-Del Toro, E.E.; Cervantes, F.J. Coupling between anammox and autotrophic denitrification for simultaneous removal of ammonium and sulfide by enriched marine sediments. Biodegradation 2016, 27, 107-118. [CrossRef]

73. Ren, Y.; Hao Ngo, H.; Guo, W.; Wang, D.; Peng, L.; Ni, B.-J.; Wei, W.; Liu, Y. New perspectives on microbial communities and biological nitrogen removal processes in wastewater treatment systems. Bioresour. Technol. 2020, 297, 122491. [CrossRef]

74. Li, X.; Sun, Y.; Wang, Z.W.; He, Z. Theoretical understanding of the optimum conditions for a mainstream granular nitritationanammox reactor coupled with anaerobic pretreatment. Sci. Total. Environ. 2019, 669, 683-691. [CrossRef]

75. Kalyuzhnyi, S.; Gladchenko, M.; Mulder, A.; Versprille, B. DEAMOX-New biological nitrogen removal process based on anaerobic ammonia oxidation coupled to sulphide-driven conversion of nitrate into nitrite. Water Res. 2006, 40, 3637-3645. [CrossRef] [PubMed]

76. You, Q.-G.; Wang, J.-H.; Qi, G.-X.; Zhou, Y.-M.; Guo, Z.-W.; Shen, Y.; Gao, X. Anammox and partial denitrification coupling: A review. RSC Adv. 2020, 10, 12554-12572. [CrossRef]

77. Gani, K.M.; Awolusi, O.O.; Khan, A.A.; Kumari, S.; Bux, F. Potential strategies for the mainstream application of anammox in treatment of anaerobic effluents-A review. Crit. Rev. Environ. Sci. Technol. 2020, 1-28. [CrossRef]

78. Yuan, Y.; Li, X.; Li, B.-L. Autotrophic nitrogen removal characteristics of PN-anammox process enhanced by sulfur autotrophic denitrification under mainstream conditions. Bioresour. Technol. 2020, 316, 123926. [CrossRef] [PubMed]

79. Li, J.; Li, J.; Peng, Y.; Wang, S.; Zhang, L.; Yang, S.; Li, S. Insight into the impacts of organics on anammox and their potential linking to system performance of sewage partial nitrification-anammox (PN/A): A critical review. Bioresour. Technol. 2020, 300, 122655. [CrossRef]

80. Wang, B.; Gong, X.; Peng, Y. Simultaneous anammox-denitrification process and its emerging extensions. Chem. Eng. J. 2021, 415, 128380. [CrossRef]

81. Pedrouso, A.; Val del Rio, A.; Morales, N.; Vazquez-Padin, J.R.; Campos, J.L.; Mosquera-Corral, A. Mainstream anammox reactor performance treating municipal wastewater and batch study of temperature, $\mathrm{pH}$ and organic matter concentration cross-effects. Process Saf. Environ. Prot. 2021, 145, 195-202. [CrossRef]

82. Chen, C.; Sun, F.; Zhang, H.; Wang, J.; Shen, Y.; Liang, X. Evaluation of COD effect on anammox process and microbial communities in the anaerobic baffled reactor (ABR). Bioresour. Technol. 2016, 216, 571-578. [CrossRef] [PubMed] 